\title{
Long-term remission and biologic persistence rates: 12-year real-world data
}

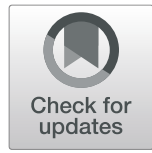

Kieran Murray ${ }^{1,2^{*}}$ D , Matthew Turk ${ }^{1,2}$, Yousef Alammari ${ }^{1,2}$, Francis Young ${ }^{1,2}$, Phil Gallagher ${ }^{1,2}$, Tajur Saber $^{3}$, Ursula Fearon ${ }^{4}$ and Douglas J. Veale $e^{1,2}$

\begin{abstract}
Background: Biologic therapies have greatly improved outcomes in rheumatoid arthritis (RA) and psoriatic arthritis (PsA). Yet, our ability to predict long-term remission and persistence or continuation of therapy remains limited. This study explores predictors of remission and persistence of the initial biologic therapy in patients after 12 years. Furthermore, outcomes with adalimumab and etanercept are compared.
\end{abstract}

Patients and methods: RA and PSA patients were prospectively recruited from a biologic clinic. Outcomes on commencing therapy, at 1 year and 12 years were reviewed. Demographics, medications, morning stiffness, patient global health score, tender and swollen joint counts, antibody status, CRP and HAQ were collected. Outcomes at 1 year and 12 years are reported and predictors of biologic persistence and EULAR-defined remission (DAS28-CRP < 2.6) are examined with univariate and multivariate analysis.

Results: A total of 403 patients (274 RA and 129 PsA) were analysed. PsA patients were more likely to be male, in fulltime employment and have completed higher education. PSA had higher remission rates than RA at both 1 year $(60.3 \%$ versus $34.5 \%, p<0.001)$ and 12 years $(91.3 \%$ versus $60.6 \%, p<0.001)$. This difference persisted when patients were matched for baseline disease activity $(p<0.001)$. Biologic continuation rates were high for RA and PsA at 1 year (49.6\% versus 58.9\%) and 12 years (38.2\% versus 52.3\%). In PsA, patients starting on etanercept had lower CRP at 12 years $(p=0.041)$. Multivariate analysis showed 1-year continuation [OR $4.28(1.28-14.38)]$ and 1-year low-disease activity [OR 3.90 (95\% Cl 1.05-14.53)] was predictive of a 12-year persistence. Persistence with initial biologic at 12 years [OR 4.98 (95\% Cl 1.83-13.56)] and male gender [OR 4.48 (95\% Cl 1.25-16.01)] predicted 12 year remission.

Conclusions: This is the first study to show better response to biologic therapy in PsA compared to RA at 12 years. Long-term persistence with initial biologic agent was high and was predicted by biologic persistence and low-disease activity at 1 year. Interestingly, PsA patients had higher levels of employment, educational attainment, and long-term remission rates compared to RA patients.

Keywords: Rheumatoid arthritis, Psoriatic arthritis, Biologics, Remission

\footnotetext{
* Correspondence: kemurray@hotmail.com

'Department of Rheumatology, St Vincent's University Hospital, Dublin 4, Ireland

${ }^{2}$ EULAR Centre for Arthritis and Rheumatic Diseases, Dublin, Ireland

Full list of author information is available at the end of the article
}

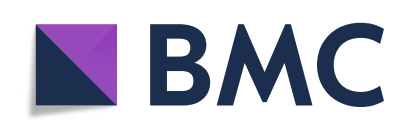

(c) The Author(s). 2021 Open Access This article is licensed under a Creative Commons Attribution 4.0 International License, which permits use, sharing, adaptation, distribution and reproduction in any medium or format, as long as you give appropriate credit to the original author(s) and the source, provide a link to the Creative Commons licence, and indicate if changes were made. The images or other third party material in this article are included in the article's Creative Commons licence, unless indicated otherwise in a credit line to the material. If material is not included in the article's Creative Commons licence and your intended use is not permitted by statutory regulation or exceeds the permitted use, you will need to obtain permission directly from the copyright holder. To view a copy of this licence, visit http://creativecommons.org/licenses/by/4.0/ The Creative Commons Public Domain Dedication waiver (http://creativecommons.org/publicdomain/zero/1.0/) applies to the data made available in this article, unless otherwise stated in a credit line to the data. 


\section{Background}

RA and PsA are the most common forms of inflammatory arthritis (IA) with a prevalence of $1 \%$ and $0.25 \%$, respectively $[1,2]$. They are chronic relapsing/remitting multisystem conditions characterised by synovitis, joint deformity, loss of function and increased mortality [36]. The economic implications for patients, their families and society are significant [7]; RA has an estimated annual economic burden of over $€ 45$ billion in Europe alone [8].

Biologic disease modifying anti-rheumatic drugs (bDMARDs) have dramatically improved outcomes in RA, PsA, psoriasis and other autoimmune conditions [9]. They are superior to methotrexate in decreasing disease activity $[10,11]$, and they improve physical function in conventional synthetic DMARD (csDMARD) failures and inhibit radiographic damage [12]. Tumour necrosis factor inhibitors (TNFis) reduce mortality and are more cardioprotective than csDMARD treatment [13, 14]. Compared to methotrexate, bDMARDs are cost-effective first-line therapies due to greater efficacy, fewer doselimiting adverse effects and lower monitoring costs [15]. The current treatment paradigm has shifted to bDMARD as first-line therapies [9]. Indeed, updated ACR guidelines advise a TNFi over traditional csDMARDs in treatment-naive patients with active PsA [16].

Numerous RCTs examine bDMARDs in IA [17-21]. However, these may not be generalizable to routine clinical practice due to strict inclusion criteria, short duration and relatively small sample sizes [22]. Registries can provide more real-world data [23-30]. Again, these may only follow patients for a limited time and, in comparison to RA, there remains a paucity of data on biologic use in PsA [24]. Given the lack of RCTs comparing TNFi, observational studies are required [31]. In this prospective study, we compare outcomes with adalimumab and etanercept. Despite new bDMARDs, these two agents continue to account for $61 \%$ of biologic prescriptions by Irish rheumatologists [32].

A meta-analysis found rates of 1 year biologic persistence, defined as a continuation of a therapy, in RA varied from 32.0 to $90.9 \%$ [33]. Less is known about a longterm biologic persistence in PsA [34]. Among German patients on subcutaneous biologics, a higher proportion of PsA patients (57.9\%) remained on therapy $\geq 12$ months compared to RA (51.9\%) [35]. In the US Corrona registry, $36.1 \%$ of PsA patients continued on their medication at 48 months. Medication continuation studies are often based on administrative data, lacking important clinical and laboratory parameters [36].

This study compares clinical, laboratory and epidemiological characteristics of a well characterised real-world cohort of RA and PsA patients commencing bDMARDs.
Many studies examining predictors of biologic continuation and remission are limited to 1 year. We examined for longer term predictors by providing 12-year outcomes and biologic continuation data. Furthermore, we compare disease activity, remission and medication continuation for the two most commonly prescribed subcutaneous bDMARDs-adalimumab and etanercept. We provide insights into patient characteristics that predict long-term disease course and biologic continuation for individual patients.

\section{Methods \\ Study design}

In 2000, a specific biologic outpatient clinic and prospective database was created to enable close monitoring of these novel therapies. This clinic is described in detail in a prior study in this journal [37]. This current study compares outcomes on commencing therapy, at 1 year and most recent review.

Baseline, 1-year (1.04 \pm 0.15 years $)$ and 12-year (11.76 \pm 2.69 years) assessments were compared. Demographics (age, gender, educational level, employment), smoking status, diagnosis, disease duration, medications, Health Assessment Questionnaire (HAQ), patient global health (PGH), tender joint count (TJC), swollen joint count (SJC), C-reactive protein (CRP), rheumatoid factor (RF) and anti-cyclic citrullinated peptide antibody (ACPA) status and erosive status on X-rays of the hands and feet were reviewed. Erosive status was defined by the presence or absence of erosions on standard plain Xrays of the hands and feet as reported by a consultant musculoskeletal radiologist. The 28-joint count Disease Activity Score with CRP (DAS28-CRP) was calculated, as it is a validated measure in both RA and PsA clinical trials, and remission was classified as DAS28-CRP $<2.6$ according to the European League Against Rheumatism (EULAR) criteria [38, 39]. Disease activity was defined as low (DAS28-CRP $\leq 3.2)$, moderate $(3.2<$ DAS28-CRP $\leq$ 5.1) or high (DAS28-CRP > 5.1) [38, 40, 41]. Patients who did not commence a named biologic at the clinic review were excluded from the study $(n=64)$.

\section{Statistical analysis}

Data analyses were performed using SPSS 26. Nominal data is presented as frequencies and percentages. Normally distributed continuous and ordinal data are presented as the mean and standard deviation (SD), while non-normally distributed data are presented as the median (range). Between group differences were analysed using unpaired 2-tailed $t$ tests, Pearson chi-square, Fisher's exact test or Mann-Whitney $U$ test as appropriate.

Univariate analysis was used to identify predictors of (i) persistence with initial biologic agent and (ii) remission at 12 years. All factors that demonstrated a 
significant association within the univariate models $(p<$ 0.20 ) were then used to create a multivariate model and evaluated with logistic regression analysis. Age and education were retained in the multivariate models even if not significant as is standard practice for these biologically important confounders. Odds ratios (ORs) from these two final models quantified the effect of each factor as a predictor of remission or biologic continuation.

\section{Results}

\section{Patient characteristics}

A total of 403 patients (274 RA and 129 PsA) were followed-up. RA patients tended to be older, more commonly female and had more severe disease with higher HAQ scores and more erosions (Table 1). Patients with PsA had higher educational attainment and employment levels (Table 1). To check for confounders explaining the difference in educational levels, a subset of male patients $40-59$ years old were analysed. The difference in educational level maintained statistical significance.

Table 1 Baseline characteristics

\begin{tabular}{llll}
\hline & RA $(\boldsymbol{n}=\mathbf{2 7 4})$ & PsA $(\boldsymbol{n}=\mathbf{1 2 9})$ & $\boldsymbol{p}$ \\
\hline Age, years & $55 \pm 11.9$ & $44.8 \pm 12.2$ & $<0.001$ \\
Female & $207(75.5 \%)$ & $69(53.5 \%)$ & $<0.001$ \\
Disease duration, years & $9(0-51)$ & $8(0-40)$ & 0.030
\end{tabular}

\section{Education level completed}

$\begin{array}{llll}\text { Primary School } & 246(100 \%) & 98(100 \%) & \text { NS } \\ \text { Secondary School } & 176(71.5 \%) & 90(91.8 \%) & <0.001 \\ \text { University } & 56(22.8 \%) & 59(60.2 \%) & <0.001\end{array}$

$\begin{array}{llll}\begin{array}{l}\text { Employment } \\ \text { Employed }\end{array} & 37(66.1 \%) & 31(91.2 \%) & 0.008 \\ \text { Unemployed } & 8(14.3 \%) & 1(2.9 \%) & \text { NS } \\ \text { Student } & 0 & 1(2.9 \%) & \text { NS } \\ \text { Other } & 11(19.6 \%) & 1(2.9 \%) & 0.027 \\ \text { Hours worked, weekly } & 37.2(11.7) & 41.1(9.1) & \text { NS }\end{array}$

\section{Smoking status}

$\begin{array}{llll}\text { Never } & 89(35.6 \%) & 50(45.5 \%) & \text { NS } \\ \text { Ex } & 94(37.6 \%) & 35(31.8 \%) & \\ \quad \text { Current } & 67(26.8 \%) & 25(22.7 \%) & \\ \text { HAQ score } & 1.3(0.64) & 0.89(0.64) & <0.001 \\ \text { EMS, minutes } & 30(0-1440) & 30(0-1440) & \text { NS } \\ \text { RF positive } & 195(77.1 \%) & 2(2.2 \%) & <0.001 \\ \text { ACPA positive } & 31(79.5 \%) & 0(0 \%) & <0.001 \\ \text { Erosions* } & 90(47.1 \%) & 28(31.5 \%) & 0.013\end{array}$

Values are expressed as $n$ (\%), mean (SD) or median (range) $H A Q$ Health Assessment Questionnaire, EMS early morning stiffness, RF rheumatoid factor, ACPA Anti-citrullinated protein antibodies *On X-rays of the hands and feet
52.4\% of patients with PsA were university graduates versus $19.2 \%$ in RA $(p=0.014)$. In this subgroup, there was no significant difference in employment $(p=0.261)$.

\section{Medications}

Patient medications are shown in Table 2. At baseline review, the majority of RA patients commenced adalimumab, with most PsA patients starting etanercept. A small number of patients in both groups received infliximab and $4.4 \%$ of RA patients started on rituximab. Figure 1 shows the rate of persistence with the original bDMARD. There was no significant difference between RA and PsA at 1 year $(p=0.088)$ or 12 years $(p=0.068)$. At 12 years, $20.2 \%$ of RA and $11.9 \%$ of PsA patients were no longer on a bDMARD and $14.3 \%$ of RA and $9.5 \%$ of PsA patients were prescribed a novel bDMARD/small molecule inhibitor (Table 2). Methotrexate use was higher in RA at all three time points (Table 2).

\section{Clinical response}

Table 2 shows the dramatic improvement in clinical outcomes in both diseases. Median TJC improved from nine to zero in RA and six to zero in PsA. SJC improved from nine to zero in RA and five to zero in RA and PsA, respectively. CRP was higher in RA, as expected, at all three points. The rate of progression of erosions was also higher among patients with RA at both 1 year $(28.1 \%$ versus $8.6 \%, p=0.003)$ and 12 years $(31.9 \%$ versus $15.0 \%, p=$ $0.005)$. DAS28-CRP was higher in RA at all three time points (Fig. 2a). One year and 12-year DAS28-CRP remained higher in RA, even in a cohort of patients matched for disease activity at baseline (moderate disease activity) (Fig. 2b). Remission rates were higher in PsA at all three timepoints (Fig. 3a). Even in the subgroup matched for baseline DAS-28 CRP, both 1 year and 12-year remission rates remained higher in PsA (Fig. 3b).

\section{Predictors of continuation and remission}

The multivariate analysis focused on predictors of a 12year continuation with initial bDMARD and a 12-year remission. One year continuation [OR 4.28 (1.28-14.38)] and 1-year low-disease activity [OR 3.90 (95\% CI 1.0514.53)] predicted continuation (Table 3). A 12-year continuation [OR 4.98 (95\% CI 1.83-13.56)] and male gender [OR 4.48 (95\% CI 1.25-16.01)] predicted remission (Table 4).

\section{Comparative analysis of subcutaneous bDMARDs}

In this study, $89.1 \%(n=359)$ of patients were on one of the two subcutaneous bDMARDs, etanercept and adalimumab. In comparison to etanercept, patients on adalimumab were more likely to be older $(53.7 \pm 12.4$ years versus $49.4 \pm 13.0$ years, $p=0.001$ ) and have RA [144 (75.4\%) versus 100 (59.5\%), $p=0.001]$. When separated 
Table 2 A comparison of rheumatoid arthritis and psoriatic arthritis outcomes at biologic initiation, one year and 12 year reviews

\begin{tabular}{|c|c|c|c|c|c|c|c|c|c|}
\hline & \multicolumn{3}{|l|}{ Baseline } & \multicolumn{3}{|l|}{1 Year Review } & \multicolumn{3}{|c|}{12 Year Review } \\
\hline & $\mathrm{RA}(n=274)$ & PsA $(n=129)$ & $p$ & $\mathrm{RA}(n=203)$ & PsA $(n=96)$ & $p$ & RA $(n=179)$ & PsA $(n=87)$ & $p$ \\
\hline \multicolumn{10}{|l|}{ Biologic } \\
\hline Adalimumab & $144(52.6 \%)$ & 47 (36.4\%) & 0.002 & $76(44.7 \%)$ & $27(31.0 \%)$ & 0.034 & $43(25.6 \%)$ & $28(33.3 \%)$ & NS \\
\hline Etanercept & $100(36.5 \%)$ & $68(52.7 \%)$ & 0.002 & $62(36.5 \%)$ & $45(51.7 \%)$ & 0.019 & $48(28.6 \%)$ & $30(35.7 \%)$ & NS \\
\hline Infliximab & $18(6.6 \%)$ & $14(10.9 \%)$ & NS & $13(7.6 \%)$ & $11(12.6 \%)$ & NS & $3(1.8 \%)$ & $8(9.5 \%)$ & 0.004 \\
\hline Rituximab & $12(4.4 \%)$ & 0 & 0.011 & $4(2.4 \%)$ & 0 & NS & $16(9.5 \%)$ & 0 & 0.004 \\
\hline Other $^{a}$ & 0 & 0 & & $1(0.6 \%)$ & 0 & NS & $24(14.3 \%)$ & $8(9.5 \%)$ & NS \\
\hline None & 0 & 0 & & $14(5.1 \%)$ & $4(3.1 \%)$ & NS & $34(20.2 \%)$ & $10(11.9 \%)$ & NS \\
\hline Biologic persistence & $\mathrm{n} / \mathrm{a}$ & $\mathrm{n} / \mathrm{a}$ & $\mathrm{n} / \mathrm{a}$ & $136(49.6 \%)$ & 76 (58.9\%) & NS & $66(38.2 \%)$ & $45(52.3 \%)$ & NS \\
\hline Methotrexate & $176(64.2 \%)$ & $35(27.3 \%)$ & $<0.001$ & $108(64.8 \%)$ & $21(24.4 \%)$ & $<0.001$ & $72(42.2 \%)$ & $22(25.9 \%)$ & 0.008 \\
\hline PGH, mm & $60(0-100)$ & $50(0-100)$ & NS & $30(0-100)$ & $20(0-90)$ & $<0.001$ & $50(0-100)$ & $5(0-100)$ & $<0.001$ \\
\hline TJC28 & $9(0-28)$ & $6(0-28)$ & $<0.001$ & $1(0-28)$ & $0(0-20)$ & $<0.001$ & $0(0-19)$ & $0(0-2)$ & 0.019 \\
\hline SJC28 & $9(0-28)$ & $5(0-28)$ & $<0.001$ & $1(0-28)$ & $0(0-25)$ & $<0.001$ & $0(0-15)$ & $0(0-2)$ & $<0.001$ \\
\hline CRP, mg/L & $16(2-158)$ & $9(0-108)$ & $<0.001$ & $4(1-138)$ & $4(0-41)$ & 0.034 & $3(1-65)$ & $2(1-46)$ & $<0.001$ \\
\hline \multicolumn{10}{|l|}{ Disease Activity } \\
\hline Low & $9(3.5 \%)$ & $13(11.1 \%)$ & 0.003 & $91(55.2 \%)$ & $60(82.2 \%)$ & $<0.001$ & $83(79.8 \%)$ & $22(95.7 \%)$ & NS \\
\hline Moderate & 89 (34.4\%) & $65(55.6 \%)$ & $<0.001$ & $58(35.2 \%)$ & $10(13.7 \%)$ & 0.001 & $20(19.2 \%)$ & $1(4.3 \%)$ & 0.012 \\
\hline High & $160(61.8 \%)$ & 39 (33.3\%) & $<0.001$ & $16(9.7 \%)$ & $3(4.1 \%)$ & NS & $1(1 \%)$ & $0(0 \%)$ & NS \\
\hline Erosion progression & & & & 36 (28.1\%) & $5(8.6 \%)$ & 0.003 & 51 (31.9\%) & $12(15.0 \%)$ & 0.005 \\
\hline
\end{tabular}

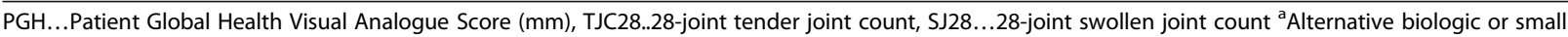
molecule inhibitor-golimumab, certolizumab, tocilizumab, abatacept, secukinumab, ustekinumab, ixekizumab tofacitinib or baricitinib

by disease, patients on each agent were well matched (Supplementary Tables 1 and 2). There were no significant differences in rates of continuation with initial bDMARD or methotrexate use in either disease (Supplementary Table 3 and 4). Clinical response was excellent with both agents. There were no significant differences between agents in RA at any timepoint (Supplementary Table 3). In PsA, patients on etanercept had a higher baseline DAS28-CRP (mean $4.95 \pm 1.10$ ) than those on adalimumab (mean $4.45 \pm 0.93) \quad(p=0.011)$

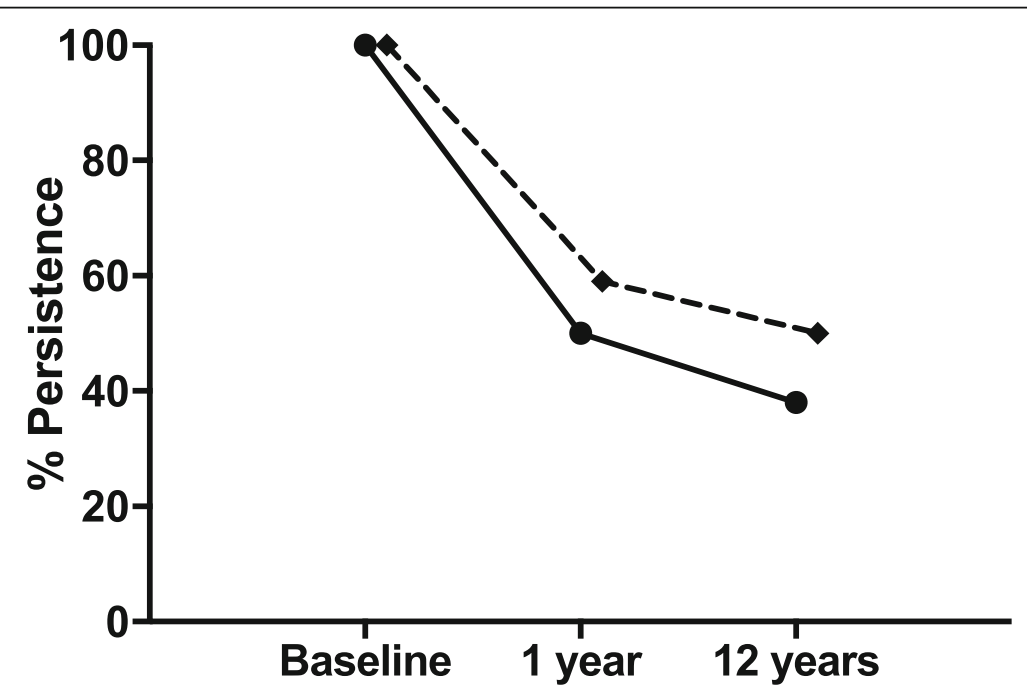

Fig. 1 A comparison of persistence with initial biologic agent over time in rheumatoid and psoriatic arthritis. Persistence rates with original biologic agent in rheumatoid arthritis is represented by the solid line $(n=274)$ and psoriatic arthritis $(n=129)$ by the dotted line 
Table 3 Univariate and multivariate analyses for predictors of persistence with initial biologic at 12 years

\begin{tabular}{llll}
\hline & Univariate & Multivariate & \\
\cline { 3 - 4 } & $\boldsymbol{p}$ & OR $(\mathbf{9 5 \%} \mathrm{Cl})$ & $\boldsymbol{p}$ \\
\hline Persistence at 1 year & 0.011 & $4.28(1.28-14.38)$ & 0.019 \\
One-year low-disease activity & $<0.001$ & $3.90(1.05-14.53)$ & 0.042 \\
Smoker/ex-smoker at baseline & 0.055 & $0.39(0.14-1.10)$ & 0.074 \\
Completed university & 0.033 & $1.84(0.54-6.27)$ & 0.333 \\
Etanercept at baseline & 0.020 & $1.51(0.56-4.07)$ & 0.411 \\
Baseline alcohol use & 0.135 & $1.37(0.47-4.04)$ & 0.565 \\
Infliximab at baseline & 0.156 & $0.50(0.05-5.00)$ & 0.557 \\
Male gender & 0.061 & $0.75(0.24-2.38)$ & 0.623 \\
Finished secondary school & 0.010 & $0.85(0.26-2.78)$ & 0.784 \\
Remission at 1 year & 0.002 & $0.87(0.27-2.86)$ & 0.823 \\
Baseline methotrexate use & 0.084 & $1.07(0.40-2.89)$ & 0.897 \\
Age > 50 years & 0.797 & $0.97(0.32-2.90)$ & 0.950 \\
\hline
\end{tabular}

(Supplementary Table 4). At 12 years, PsA patients initially commenced on etanercept had a slightly lower CRP (median $2.1 \mathrm{mg} / \mathrm{L}$, range 1-31) compared with adalimumab (median $1.1 \mathrm{mg} / \mathrm{L}$, range 1-46) (Supplementary Table 4).

\section{Discussion}

This is the first study to show better 12 year bDMARD response in PsA compared to RA. Overall, the patients have excellent outcomes, with $91.3 \%$ of PsA and $60.6 \%$ of RA patients in remission at 12 years. This compares favourably to other long-term studies [42-44]. Progress of erosions was also less frequent [45]. Despite lower levels of methotrexate use, disease activity was lower in PsA based on all outcome metrics at all time points except for baseline patient global health (PGH). Interestingly, PGH has been shown to be a confounder in both diseases [46-48]. This study delivers some clear messages; PsA is generally a milder clinical phenotype than RA and patients with PsA respond better to bDMARD therapies. In comparative analysis of subcutaneous bDMARDs, outcomes were very similar for adalimumab and etanercept in both RA and PsA.

Consistent with prior studies, the RA patients tended to be older, more commonly female and had more severe disease (with higher HAQ scores and more erosions) [37]. With respect to demographics, patients with PsA had higher educational attainment and employment levels. In a subgroup matched for age and gender, levels of university education remained higher in patients with PsA. This is the first study to show differences in educational attainment between RA and PsA. The prevalence of IA is increased among patients with psoriasis, ranging from 7 to $42 \%$, compared with a general population estimate of 2 to $3 \%$ [49]. In about 85\%, psoriasis precedes articular involvement [4]. Perhaps, better educated individuals with psoriasis may be more aware of their increased risk of PsA and thus present to medical attention more promptly. A previous study in our unit showed PsA patients with low education status were significantly more likely to have a diagnostic delay of $>2$ years (OR 2.09, $p=0.02$ ) [50]. In that study, a 6-month delay from symptom onset to the first visit with a rheumatologist contributes to the development of peripheral joint erosions and worse long-term physical function [50]. Late presentation is also a poor prognostic factor in RA [51, 52].

Demographics can be predictive of outcomes in IA. This study and many others show males have better outcomes and response to bDMARDs in IA $[53,54]$. A Danish study showed a 2-fold lower risk of RA among those with the longest formal education compared with those having the lowest level of education [55]. An American study found educational level to be an important marker of RA clinical status [56]. Individuals who did not complete high school had worse outcomes according to ESR, joint count, grip strength and walking time [56]. In our study, the unemployment rate in RA was $14.3 \%$, compared to the national unemployment rate of $4.3 \%$. In the current study, $28.5 \%$ of RA patients did not complete secondary school. Patient education is important in medication adherence, and patient information should be delivered at a 13-14-year-old reading level [57]. However, we have previously shown much of the health information available for arthritis is above this level [57]. It is important to recognise social determinants of health when we interact with patients in clinic in order to optimise their outcomes.

In RA, mean DAS28-CRP fell from $5.28 \pm 1.10$ at baseline to $2.51 \pm 0.99$ at 12 years $(p<0.001)$. In PsA, the mean baseline DAS28-CRP was $4.60 \pm 1.11$ and fell to $1.68 \pm 0.69$ after 12 years $(p<0.001)$. Even when matched for disease activity at baseline, PsA had a lower mean DAS28-CRP compared to RA at 1 year and 12 years suggesting a better response to bDMARD therapy.

Many prior studies examining predictors of biologic persistence and remission are limited to 1 year. In contrast, we examined for predictors after 12 years of treatment. Our multivariate analyses highlight the difficulty in predicting long-term continuation and remission at bDMARD commencement. In the multivariate model, no baseline factors were predictive of continuation with initial bDMARD. Male gender, however, was predictive of remission. Our observation that male gender is associated with a greater rate of remission is consistent with prior studies $[42,53,58,59]$. The underlying mechanism for this relationship remains poorly understood. Male sex hormones seem protective in IA. Men with RA tend 


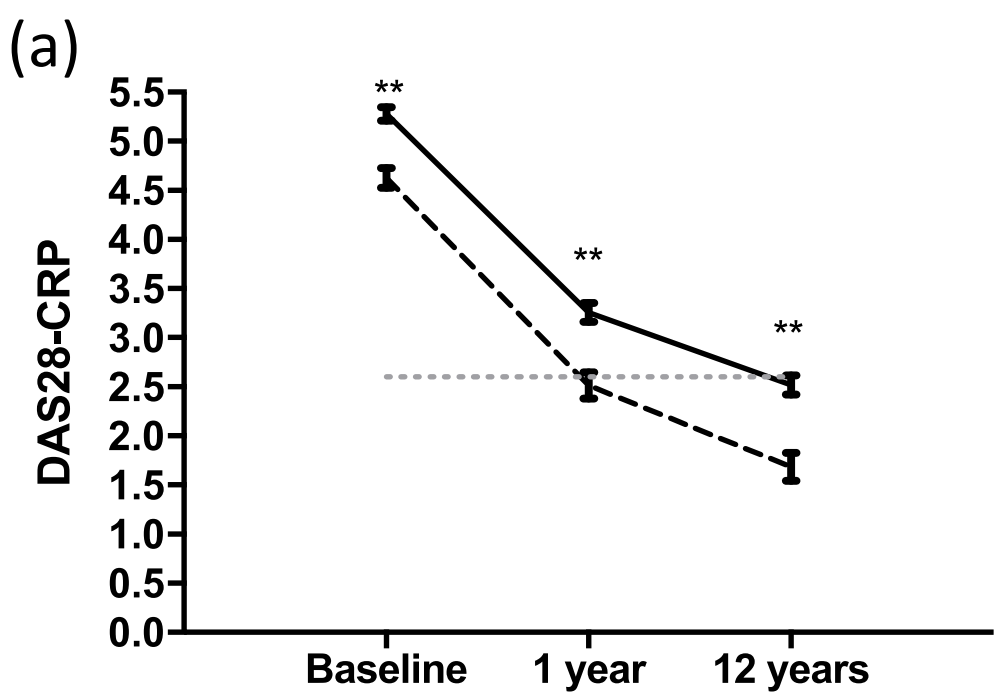

(b)

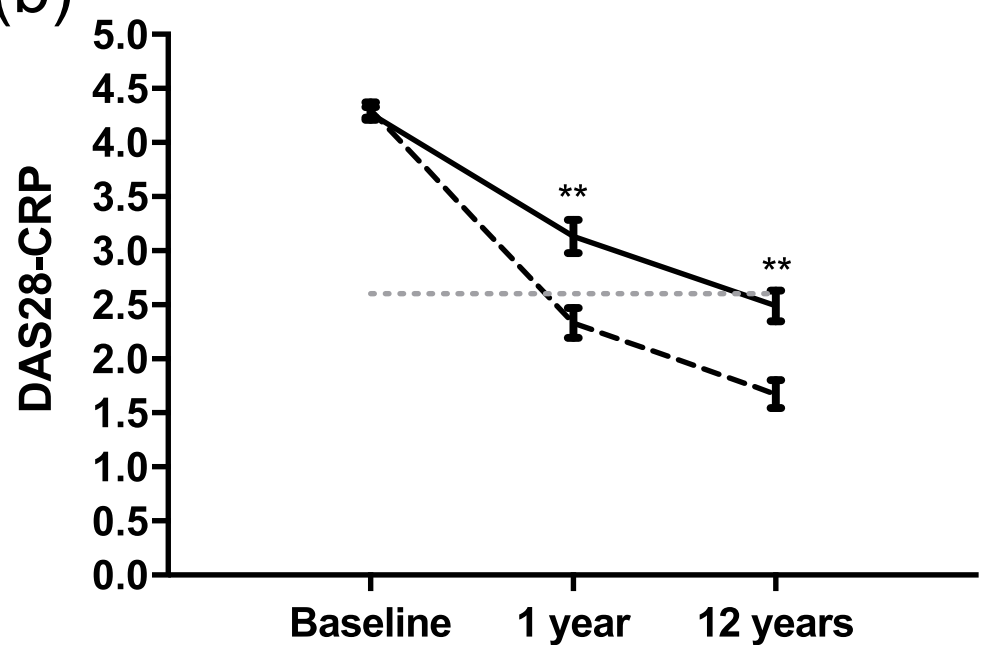

Fig. 2 A comparison of DAS28-CRP in RA and PSA across 12 years. a Line graph representing DAS28-CRP responses to biologic therapy at 1 year and 12 years in RA [solid line $(n=274)$ ] and PSA [dotted black line $(n=129)]$. Remission is represented by the dotted grey line at DAS28-CRP value of 2.6. DAS28-CRP is significantly lower in PsA at all time points. $\mathbf{b}$ Line graph representing DAS28-CRP responses to biologic therapy at 1 year and 12 years in a cohort matched for baseline DAS28-CRP (moderate disease activity) in RA [solid line $(n=89)$ ] and PsA [dotted black line ( $n=$ 65)]. Remission is represented by the dotted grey line at DAS28-CRP value of 2.6. Values are expressed as mean $+/-$ SEM; ** $p<0.001$ between RA and PsA at that timepoint

to have higher levels serum of oestrodiol levels and lower levels of androgenic steroids including testosterone and dehydroepiandrosterone compared to healthy controls [60, 61]. TNF blockade affects hormone levels in the synovial fluid prior to serum levels and seems to block the aromatase induced conversion of androgens to oestrogens [62].

One-year bDMARD persistence and 1-year lowdisease activity were significant predictors of long-term bDMARD continuation. This is useful information in clinical practice. Continuation with initial bDMARD and quiescent disease at 1 year is predictive of longer term outcomes. A long-term bDMARD continuation was predictive of remission. Interestingly, methotrexate use is low, particularly at the 12 year review $(42.2 \%$ in RA and $25.9 \%$ in PsA). Methotrexate is the most widely used first-line RA therapy $[63,64]$. Methotrexate is therapeutically effective, cost-effective and, unlike other csDMARDs, has a mortality benefit in RA (hazard ratio 0.4 (95\% CI $0.2-0.8)[65,66]$. The addition of methotrexate to bDMARD therapy has been shown to decrease disease activity, slow radiographic progression and improve function in a RCT [67]. However, methotrexate has significant limitations. It may take 6 months to 


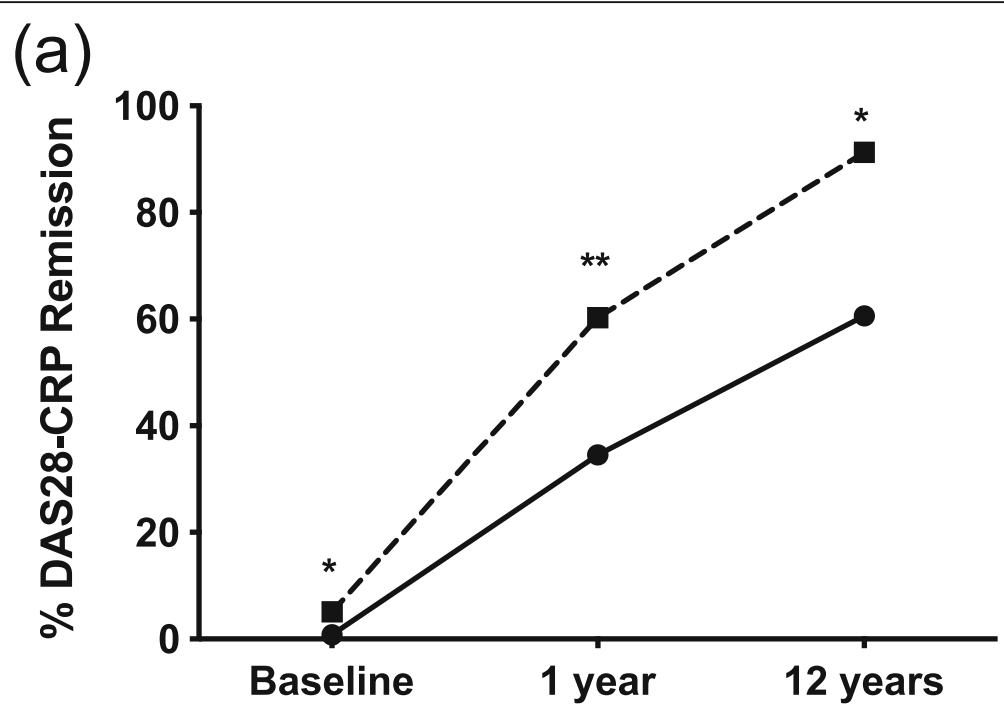

(b)

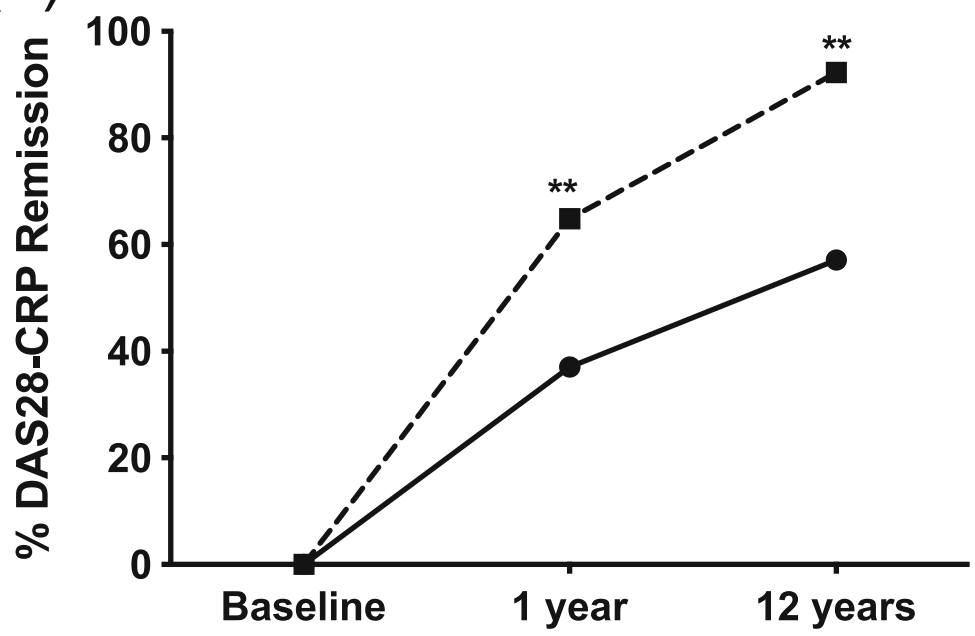

Fig. 3 A comparison of rates of DAS28-CRP remission over time. a PsA represented by the dotted line $(n=129)$ has higher remission rates at all time points when compared to RA $(n=274)$, represented by solid black line. $\mathbf{b}$ In patients matched for baseline disease activity [moderate disease activity $(n=154)$ ], remission rates are higher in PsA at both 1 year and 12 years ${ }^{*} p<0.05,{ }^{* *} p<0.001$ between RA and PsA at that timepoint

Table 4 Univariate and multivariate analyses for predictors of a 12-year remission

\begin{tabular}{llll}
\hline & Univariate & Multivariate & \\
\cline { 3 - 4 } & $\boldsymbol{p}$ & OR (95\% Cl) & $\boldsymbol{p}$ \\
\hline 12-year biologic persistence & 0.002 & $4.98(1.83-13.55)$ & 0.002 \\
Male gender & 0.003 & $4.48(1.25-16.01)$ & 0.021 \\
University graduate & 0.057 & $2.49(0.68-9.09)$ & 0.166 \\
1-year remission & 0.017 & $2.01(0.71-5.71)$ & 0.190 \\
Age $>$ 50 years & 0.127 & $1.15(0.37-3.61)$ & 0.813 \\
\hline
\end{tabular}

achieve full therapeutic response [18, 68, 69]. Despite widespread methotrexate use in PsA, we lack randomised placebo-controlled trials showing a decrease in radiographic progression or benefits sustained beyond 6 months [70]. In one study of methotrexate monotherapy in PsA, $<20 \%$ of patients achieved minimal disease activity at 6 months [71]. Adverse effects include nausea, headaches, cytopenia, hepatotoxicity, pulmonary toxicity and teratogenicity [72-75]. Blood monitoring is burdensome. Current guidelines suggest taking full blood count, liver function tests and urea and electrolytes on 7 separate occasions within the first 18 weeks of therapy [76]. Some guidelines also advise alcohol abstinence [77]. Given the difficulties associated with use and the high 
remission rates in our cohort it is, perhaps, not surprising methotrexate use is low.

One- and 12-year persistence rates were $49.6 \%$ and $38.2 \%$ in RA and $58.9 \%$ and $52.3 \%$ in PsA, respectively. Numerous studies show a higher bDMARD continuation in spondyloarthropathies such as PsA when compared to RA [78, 79]. A 2014 meta-analysis of $>200,000$ RA patients on bDMARD therapy found continuation rates of $73 \%$ at 1 year and $48 \%$ at 4 years [80]. In the BSR register, $69.2 \%$ of PsA patients were persistent with initial bDMARD at 2.3 years [81]. An Italian registry study found bDMARD continuation levels of $85 \%$ at 1 year and $64 \%$ at 3 years [78].

In the current study, both of the subcutaneous bDMARDs (etanercept and adalimumab) commenced at baseline showed excellent clinical outcomes. There were no differences in remission or continuation rate by initial bDMARD agent in either disease. Indeed, there were no significant differences in any clinical outcome measure in RA. In PsA, patients on etanercept at baseline also had a lower CRP at 12 years $(p=0.041)$. However, given the normal values in both groups, this is of dubious significance.

Strengths of this study include the large cohort of realworld patients with detailed clinical, laboratory and radiological outcomes. We are not aware of any study of IA outcomes with bDMARD therapy with such a long follow-up period. We highlight important demographic and outcome differences between RA and PsA and identify predictors of both long-term remission and bDMARD continuation. We compare 12-year outcomes for adalimumab and etanercept. An important comparison given these two agents still account for the majority of bDMARD prescriptions for IA in Ireland [32]. One limitation of this study is the patients lost to follow-up, which is inevitable in a real-world study of patients. Another limitation is that DAS28-CRP defined remission does not account for important extra-articular manifestations of psoriatic arthritis, such as the skin, nail, entheseal and spinal involvement, although this was not an aim of this study.

\section{Conclusion}

In conclusion, a greater percentage of PsA patients achieves remission on bDMARD therapy compared to RA patients. Both achieve higher frequencies of remission compared to previous analyses of csDMARD therapy alone. PsA patients had significantly higher levels of employment and education. One-year bDMARD persistence and low-disease activity at 1 year were predictive of a 12-year persistence. Male gender and 12-year persistence predicted a 12-year remission. In a comparison of adalimumab and etanercept, outcomes were very well matched with no differences in remission or continuation rate in either RA or PsA.

\section{Supplementary Information}

The online version contains supplementary material available at https://doi. org/10.1186/s13075-020-02380-z.

Additional file 1: Table S1. Baseline demographics of RA patients on subcutaneous biologics. Table S2. Baseline demographics of PsA patients on subcutaneous biologics. Table S3. Clinical outcomes of RA patients by initial subcutaneous biologic. Table S4. Clinical outcomes of PsA patients by initial subcutaneous biologic.

\section{Acknowledgements}

KM is in receipt of a University College Dublin Newman Fellowship sponsored by AbbVie.

\section{Authors' contributions}

KM and MT were involved in data entry, data analysis and initial drafting of the manuscript. YA, FY and PG were involved in data entry. TS created the database and entered baseline data. DJV conceptually designed the study. UF and DJV were involved in drafting the manuscript. The corresponding author had the final responsibility for the decision to submit for publication. The authors read and approved the final manuscript.

\section{Funding}

St. Vincent's University Hospital. In addition, KM is in receipt of a University College Dublin Newman Fellowship sponsored by AbbVie. AbbVie had no role in the study design or in the collection, analysis, or interpretation of the data, the writing of the manuscript, or the decision to submit the manuscript for publication. Publication of this article was not contingent upon approval by AbbVie.

\section{Availability of data and materials}

The datasets used and analysed during the current study are available from the corresponding author on reasonable request.

\section{Ethics approval and consent to participate}

All treatment was fully in compliance with the Helsinki Declaration and the analysis was approved by the St Vincent's University Hospital ethics committee.

\section{Consent for publication}

Not applicable.

\section{Competing interests}

The authors report no conflicts of interests.

\section{Author details}

${ }^{1}$ Department of Rheumatology, St Vincent's University Hospital, Dublin 4, Ireland. ${ }^{2}$ EULAR Centre for Arthritis and Rheumatic Diseases, Dublin, Ireland. ${ }^{3}$ Lady Reading Hospital, Soekarno Rd, PTCL Colony Peshawar, Khyber Pakhtunkhwa 25000, Pakistan. ${ }^{4}$ Molecular Rheumatology, School of Medicine, Trinity Biomedical Sciences Institute, Trinity College Dublin, Dublin D06 R590, Ireland.

Received: 4 October 2020 Accepted: 3 December 2020 Published online: 13 January 2021

\section{References}

1. Symmons D, Turner G, Webb R, Asten P, Barrett E, Lunt M, et al. The prevalence of rheumatoid arthritis in the United Kingdom: new estimates for a new century. Rheumatology (Oxford). 2002:41:793-800.

2. Gelfand JM, Gladman DD, Mease PJ, Smith N, Margolis DJ, Nijsten T, et al. Epidemiology of psoriatic arthritis in the population of the United States. J Am Acad Dermatol. 2005:53:573.

3. Wong $\mathrm{KL}$, Lee $\mathrm{KBL}$, Tai $\mathrm{BC}$, Law $\mathrm{P}$, et al. Injectable cultured bone marrowderived mesenchymal stem cells in varus knees with cartilage defects undergoing high tibial osteotomy: a prospective, randomized controlled clinical trial with 2 years' follow-up. Arthroscopy. 2013;29:2020-8.

4. Gladman DD, Shuckett R, Russell ML, Thorne JC, Schachter RK. Psoriatic arthritis (PSA)--an analysis of 220 patients. Q J Med. 1987;62:127-41.

5. Moll JM, Wright V. Psoriatic arthritis. Semin Arthritis Rheum. 1973;3:55-78. 
6. Veale DJ, Barnes L, Rogers S, FitzGerald O. Immunohistochemical markers for arthritis in psoriasis. Ann Rheum Dis. 1994;53:450-4.

7. Taylor PC, Moore A, Vasilescu R, Alvir J, Tarallo M. A structured literature review of the burden of illness and unmet needs in patients with rheumatoid arthritis: a current perspective. Rheumatol Int. 2016;36:685-95.

8. Lundkvist J, Kastäng F, Kobelt G. The burden of rheumatoid arthritis and access to treatment: health burden and costs. Eur J Health Econ. 2008;8:49-60.

9. Burmester GR, Pope JE. Novel treatment strategies in rheumatoid arthritis. Lancet. 2017;389:2338-48.

10. Bathon JM, Martin RW, Fleischmann RM, Tesser JR, Schiff MH, Keystone EC, et al. A comparison of etanercept and methotrexate in patients with early rheumatoid arthritis. N Engl J Med. 2000;343:1586-93.

11. Genovese MC, Bathon JM, Martin RW, Fleischmann RM, Tesser JR, Schiff MH, et al. Etanercept versus methotrexate in patients with early rheumatoid arthritis: two-year radiographic and clinical outcomes. Arthritis Rheumatism. 2002;46:1443-50.

12. Van de Putte LBA, Atkins C, Malaise M, Sany J, Russell AS, Van Riel P, et al. Efficacy and safety of adalimumab as monotherapy in patients with rheumatoid arthritis for whom previous disease modifying antirheumatic drug treatment has failed. Ann Rheum Dis. 2004;63:508-16.

13. Jacobsson LT, Turesson C, Nilsson J-Å, Petersson IF, Lindqvist E, Saxne T, et al. Treatment with TNF blockers and mortality risk in patients with rheumatoid arthritis. Ann Rheum Dis. 2007:66:670-5.

14. Jacobsson LTH, Turesson C, Gülfe A, Kapetanovic MC, Petersson IF, Saxne T, et al. Treatment with tumor necrosis factor blockers is associated with a lower incidence of first cardiovascular events in patients with rheumatoid arthritis. J Rheumatol. 2005;32:1213-8.

15. Spalding JR, Hay J. Cost effectiveness of tumour necrosis factor-a inhibitors as first-line agents in rheumatoid arthritis. Pharmacoeconomics. 2006;24: 1221-32.

16. Singh JA, Guyatt G, Ogdie A, Gladman DD, Deal C, Deodhar A, et al. 2018 American College of Rheumatology/National Psoriasis Foundation guideline for the treatment of psoriatic arthritis. Arthritis Rheumatol. 2019;71:5-32.

17. Moreland LW, Schiff MH, Baumgartner SW, Tindall EA, Fleischmann RM, Bulpitt KJ, et al. Etanercept therapy in rheumatoid arthritis: a randomized, controlled trial. Ann Intern Med. 1999:130:478-86.

18. Moreland LW, O'Dell JR, Paulus HE, Curtis JR, Bathon JM, St. Clair EW, et al. A randomized comparative effectiveness study of oral triple therapy versus etanercept plus methotrexate in early aggressive rheumatoid arthritis: the treatment of Early Aggressive Rheumatoid Arthritis Trial. Arthritis Rheumatism. 2012;64:2824-35.

19. Mease PJ, Gladman DD, Ritchlin CT, Ruderman EM, Steinfeld SD, Choy EH, et al. Adalimumab for the treatment of patients with moderately to severely active psoriatic arthritis: results of a double-blind, randomized, placebocontrolled trial. Arthritis Rheumatism. 2005;52:3279-89.

20. Fleischmann R, Pangan AL, Song I-H, Mysler E, Bessette L, Peterfy C, et al. Upadacitinib versus placebo or adalimumab in patients with rheumatoid arthritis and an inadequate response to methotrexate: results of a phase III, double-blind, randomized controlled trial. Arthritis Rheumatol. 2019;71: 1788-800

21. Nash P, Mease PJ, Mclnnes IB, Rahman P, Ritchlin CT, Blanco R, et al. Efficacy and safety of secukinumab administration by autoinjector in patients with psoriatic arthritis: results from a randomized, placebo-controlled trial (FUTURE 3). Arthritis Research Therapy. 2018;20:47.

22. Curtis JR, Jain A, Askling J, Bridges Jr SL, Carmona L, Dixon W, Finckh A, Hyrich K, Greenberg JD, Kremer J, Listing J. A comparison of patient characteristics and outcomes in selected European and US rheumatoid arthritis registries. Semin Arthritis Rheum. 2010;40(1):2-14. WB Saunders.

23. Silman A, Symmons D, Scott DGI, Griffiths I. British society for rheumatology biologics register. Annals Rheumatic Dis. 2003;62:ii28-9.

24. Zink A, Listing J, Kary S, Ramlau P, Stoyanova-Scholz M, Babinsky K, et al. Treatment persistence in patients receiving biological agents or conventional DMARD therapy. Ann Rheum Dis. 2005;64:1274-9.

25. Hetland ML. DANBIO: a nationwide registry of biological therapies in Denmark. Clin Exp Rheumatol. 2005;23:S205.

26. Mariette X, Gottenberg J-E, Ravaud P, Combe B. Registries in rheumatoid arthritis and autoimmune diseases: data from the French registries. Rheumatology. 2011;50:222-9.

27. Askling J, Fored CM, Geborek P, Jacobsson LT, van Vollenhoven R, Feltelius $\mathrm{N}$, et al. Swedish registers to examine drug safety and clinical issues in RA. Ann Rheum Dis. 2006;65:707-12.
28. Pérez-Sola MJ, Torre-Cisneros J, Perez-Zafrilla B, Carmona L, Descalzo MA, Gómez-Reino JJ, et al. Infections in patients treated with tumor necrosis factor antagonists: incidence, etiology and mortality in the BIOBADASER registry. Medicina clinica. 2011;137:533-40.

29. Kremer J. The CORRONA database. Annals Rheumatic Dis. 2005;64:iv37-41.

30. Mikuls TR, Kazi S, Cipher D, Hooker R, Kerr GS, Richards JS, et al. The association of race and ethnicity with disease expression in male US veterans with rheumatoid arthritis. J Rheumatol. 2007;34:1480-4.

31. Hetland ML, Christensen IJ, Tarp U, Dreyer L, Hansen A, Hansen IT, et al. Direct comparison of treatment responses, remission rates, and drug adherence in patients with rheumatoid arthritis treated with adalimumab, etanercept, or infliximab: results from eight years of surveillance of clinical practice in the nationwide Danish DANBIO registry. Arthritis Rheumatism. 2010;62:22-32.

32. Kirby C. Initial analysis of prescribing trends on primary care reimbursement services hub; 2019.

33. Blum MA, Koo D, Doshi JA. Measurement and rates of persistence with and adherence to biologics for rheumatoid arthritis: a systematic review. Clin Ther. 2011;33:901-13.

34. Harrold LR, Stolshek BS, Rebello S, Collier DH, Mutebi A, Wade SW, et al. Impact of prior biologic use on persistence of treatment in patients with psoriatic arthritis enrolled in the US Corrona registry. Clin Rheumatol. 2017; 36:895-901.

35. Lyu R, Govoni M, Ding Q, Black CM, Kachroo S, Fan T, et al. Treatment persistence among patients with rheumatoid disease (RA, AS, PSA) treated with subcutaneous biologics in Germany. Rheumatol Int. 2016;36:143-53.

36. Mahlich J, Sruamsiri R. Persistence with biologic agents for the treatment of rheumatoid arthritis in Japan. Patient Preference Adherence. 2016;10:1509.

37. Saber TP, Ng CT, Renard G, Lynch BM, Pontifex E, Walsh CA, et al. Remission in psoriatic arthritis: is it possible and how can it be predicted? Arthritis Research Therapy. 2010;12:R94.

38. Vander Cruyssen B, De Keyser F, Kruithof E, Mielants H, Van den Bosch F. Comparison of different outcome measures for psoriatic arthritis in patients treated with infliximab or placebo. Ann Rheum Dis. 2007;66:138-40.

39. Wells G, Becker J-C, Teng J, Dougados M, Schiff M, Smolen J, et al. Validation of the 28-joint Disease Activity Score (DAS28) and European League Against Rheumatism response criteria based on C-reactive protein against disease progression in patients with rheumatoid arthritis, and comparison with the DAS28 based on erythrocyte sedimentation rate. Ann Rheum Dis. 2009;68:954-60.

40. Van Gestel AM, Prevoo MLL, Van't Hof MA, Van Rijswijk MH, Van de Putte LBA, Van Riel P. Development and validation of the European League Against Rheumatism response criteria for rheumatoid arthritis: comparison with the preliminary American College of Rheumatology and the World Health Organization/International League Against Rheumatism criteria. Arthritis Rheumatism. 1996;39:34-40.

41. van Gestel AM, Haagsma CJ, van Riel PL. Validation of rheumatoid arthritis improvement criteria that include simplified joint counts. Arthritis Rheumatism. 1998:41:1845-50.

42. Flouri I, Markatseli TE, Voulgari PV, Boki KA, Papadopoulos I, Settas L, et al. Comparative effectiveness and survival of infliximab, adalimumab, and etanercept for rheumatoid arthritis patients in the Hellenic Registry of Biologics: Low rates of remission and 5-year drug survival. Semin Arthritis Rheumatism. 2014;43(4):447-57. WB Saunders.

43. Simard JF, Arkema EV, Sundstrom A, Geborek P, Saxne T, Baecklund E, et al. Ten years with biologics: to whom do data on effectiveness and safety apply? Rheumatology. 2011;50:204-13.

44. Shadick NA, Gerlanc NM, Frits ML, Stolshek BS, Brady BL, lannaccone C, et al. The longitudinal effect of biologic use on patient outcomes (disease activity, function, and disease severity) within a rheumatoid arthritis registry. Clin Rheumatol. 2019;38:3081-92.

45. Machold KP, Stamm TA, Nell VPK, Pflugbeil S, Aletaha D, Steiner G, et al. Very recent onset rheumatoid arthritis: clinical and serological patient characteristics associated with radiographic progression over the first years of disease. Rheumatology. 2007;46:342-9.

46. Ujfalussy I, Koo E. Measurement of disease activity in psoriatic arthritis extended report. Zeitschrift Fur Rheumatologie. 2003;62:60-5.

47. Balogh E, Dias JM, Orr C, Mullan R, Harty L, FitzGerald O, et al. Comparison of remission criteria in a tumour necrosis factor inhibitor treated rheumatoid arthritis longitudinal cohort: patient global health is a confounder. Arthritis Research Therapy. 2013;15:R221. 
48. Madsen OR. AB0941 Patient and physician global assessments reflect strongly diverging attitudes between patients with psoriatic arthritis and their rheumatologists to severity of disease and to the relative importance of different outcome measures. Ann Rheum Dis. 2018;77:1595. https://ard. bmj.com/content/77/Suppl_2/1595.1.info.

49. Eder L, Haddad A, Rosen CF, Lee K-A, Chandran V, Cook R, et al. The incidence and risk factors for psoriatic arthritis in patients with psoriasis: a prospective cohort study. Arthritis Rheumatology. 2016;68:915-23.

50. Haroon M, Gallagher P, FitzGerald O. Diagnostic delay of more than 6 months contributes to poor radiographic and functional outcome in psoriatic arthritis. Ann Rheum Dis. 2015;74:1045-50.

51. Scott DL, Coulton BL, Symmons DPM, Popert AJ. Long-term outcome of treating rheumatoid arthritis: results after 20 years. Lancet. 1987;329:110811.

52. Symmons DP, Jones MA, Scott DL, Prior P. Longterm mortality outcome in patients with rheumatoid arthritis: early presenters continue to do well. J Rheumatol. 1998;25:1072-7.

53. Forslind K, Hafström I, Ahlmen M, Svensson B. Sex: a major predictor of remission in early rheumatoid arthritis? Ann Rheum Dis. 2007;66:46-52.

54. Højgaard P, Ballegaard C, Cordtz R, Zobbe K, Clausen M, Glintborg B, et al. Gender differences in biologic treatment outcomes-a study of 1750 patients with psoriatic arthritis using Danish Health Care Registers. Rheumatology. 2018:57:1651-60.

55. Pedersen M, Jacobsen S, Klarlund M, Frisch M. Socioeconomic status and risk of rheumatoid arthritis: a Danish case-control study. J Rheumatol. 2006; 33:1069-74.

56. Callahan LF, Pincus T. Formal education level as a significant marker of clinical status in rheumatoid arthritis. Arthritis Rheumatism. 1988:31:1346-57.

57. Murray KE, Murray TE, O'Rourke AC, Low C, Veale DJ. Readability and quality of online information on osteoarthritis: an objective analysis with historic comparison. Interact J Med Res. 2019;8:e12855

58. Atzeni F, Antivalle M, Pallavicini FB, Caporali R, Bazzani C, Gorla R, et al. Predicting response to anti-TNF treatment in rheumatoid arthritis patients. Autoimmun Rev. 2009:8:431-7.

59. Couderc M, Gottenberg J-E, Mariette X, Pereira B, Bardin T, Cantagrel A, et al. Influence of gender on response to rituximab in patients with rheumatoid arthritis: results from the autoimmunity and rituximab registry. Rheumatology. 2014;53:1788-93.

60. Tengstrand B, Carlström K, Felländer-Tsai L, Hafström I. Abnormal levels of serum dehydroepiandrosterone, estrone, and estradiol in men with rheumatoid arthritis: high correlation between serum estradiol and current degree of inflammation. J Rheumatol. 2003;30:2338-43.

61. Tengstrand B, Carlström K, Hafström I. Bioavailable testosterone in men with rheumatoid arthritis-high frequency of hypogonadism. Rheumatology. 2002;41:285-9.

62. Cutolo M, Sulli A, Capellino S, Villaggio B, Montagna P, Pizzorni C, et al. AntiTNF and sex hormones. Ann N Y Acad Sci. 2006;1069:391-400.

63. Weinblatt ME. Methotrexate in rheumatoid arthritis: a quarter century of development. Trans Am Clin Climatol Assoc. 2013;124:16.

64. Elmamoun M, Chandran V. Role of methotrexate in the management of psoriatic arthritis. Drugs. 2018;78:611-9.

65. Strand V, Cohen S, Schiff M, Weaver A, Fleischmann R, Cannon G, et al. Treatment of active rheumatoid arthritis with leflunomide compared with placebo and methotrexate. Leflunomide Rheumatoid Arthritis Investigators Group. Arch Intern Med. 1999:159:2542-50.

66. Choi HK, Hernán MA, Seeger JD, Robins JM, Wolfe F. Methotrexate and mortality in patients with rheumatoid arthritis: a prospective study. Lancet. 2002:359:1173-7.

67. van der Heijde D, Klareskog L, Rodriguez-Valverde V, Codreanu C, Bolosiu H, Melo-Gomes J, et al. Comparison of etanercept and methotrexate, alone and combined, in the treatment of rheumatoid arthritis: two-year clinical and radiographic results from the TEMPO study, a double-blind, randomized trial. Arthritis Rheumatism. 2006;54:1063-74.

68. Verstappen SMM, Jacobs JWG, Van der Veen MJ, Heurkens AHM, Schenk Y, Ter Borg EJ, et al. Intensive treatment with methotrexate in early rheumatoid arthritis: aiming for remission. Computer Assisted Management in Early Rheumatoid Arthritis (CAMERA, an open-label strategy trial). Ann Rheum Dis. 2007:66:1443-9.

69. Van Vollenhoven RF, Ernestam S, Geborek P, Petersson IF, Cöster L, Waltbrand $E_{\text {, et }}$ al. Addition of infliximab compared with addition of sulfasalazine and hydroxychloroquine to methotrexate in patients with early rheumatoid arthritis (Swefot trial): 1-year results of a randomised trial. Lancet. 2009:374:459-66.

70. Wilsdon TD, Whittle SL, Thynne TR, Mangoni AA. Methotrexate for psoriatic arthritis. Cochrane Database of Systematic Reviews; 2019.

71. Sheane BJ, Thavaneswaran A, Gladman DD, Chandran V. Attainment of minimal disease activity using methotrexate in psoriatic arthritis. J Rheumatol. 2016:43:1718-23.

72. Lateef O, Shakoor N, Balk RA. Methotrexate pulmonary toxicity. Expert Opin Drug Saf. 2005:4:723-30.

73. Weinblatt ME. Toxicity of low dose methotrexate in rheumatoid arthritis. J Rheumatol Supplement. 1985:12:35-9.

74. Madhok R, Capell HA. Outstanding issues in use of disease-modifying agents in rheumatoid arthritis. Lancet. 1999;353:257-8.

75. Murray KE, Moore L, O'Brien C, Clohessy A, Brophy C, Minnock P, et al. Updated pharmacological management of rheumatoid arthritis for women before, during, and after pregnancy, reflecting recent guidelines. Ir J Med Sci. 2019;188:169-72.

76. Ledingham J, Gullick N, Irving K, Gorodkin R, Aris M, Burke J, et al. BSR and BHPR guideline for the prescription and monitoring of non-biologic disease-modifying anti-rheumatic drugs. Rheumatology. 2017;56:865-8.

77. Price S, James C, Deighton C. Methotrexate use and alcohol. Clin Experimental Rheumatology-Incl Supplements. 2010;28:S114.

78. Scirè CA, Caporali R, Sarzi-Puttini P, Frediani B, Di Franco M, Tincani A, et al. Drug survival of the first course of anti-TNF agents in patients with rheumatoid arthritis and seronegative spondyloarthritis: analysis from the MonitorNet database. Clin Exp Rheumatol. 2013:31:857-63.

79. Carmona L, Gómez-Reino JJ. Survival of TNF antagonists in spondylarthritis is better than in rheumatoid arthritis. Data from the Spanish registry BIOBADASER. Arthritis Res Therapy. 2006;8:R72.

80. Souto A, Maneiro JR, Gómez-Reino JJ. Rate of discontinuation and drug survival of biologic therapies in rheumatoid arthritis: a systematic review and meta-analysis of drug registries and health care databases. Rheumatology. 2015:55:523-34.

81. Saad AA, Ashcroft DM, Watson KD, Hyrich KL, Noyce PR, Symmons DPM, et al. Persistence with anti-tumour necrosis factor therapies in patients with psoriatic arthritis: observational study from the British Society of Rheumatology Biologics Register. Arthritis Research Therapy. 2009;11:R52.

\section{Publisher's Note}

Springer Nature remains neutral with regard to jurisdictional claims in published maps and institutional affiliations.

Ready to submit your research? Choose BMC and benefit from:

- fast, convenient online submission

- thorough peer review by experienced researchers in your field

- rapid publication on acceptance

- support for research data, including large and complex data types

- gold Open Access which fosters wider collaboration and increased citations

- maximum visibility for your research: over $100 \mathrm{M}$ website views per year

At BMC, research is always in progress.

Learn more biomedcentral.com/submission 